\title{
Intestinal Parasites in an Ottoman Period Latrine from Acre (Israel) Dating to the Early 1800s CE
}

\author{
William H. Eskew1, Marissa L. Ledger', Abigail Lloyd', Grace Pyles', Joppe Gosker², Piers D. Mitchell ${ }^{1 *}$ \\ ${ }^{1}$ Department of Archaeology, University of Cambridge, UK; ${ }^{2}$ ssrael Antiquities Authority, Akko, Israel
}

\begin{abstract}
The aim of this study is to determine the species of parasites that affected the inhabitants of the city of Acre on the coast of the eastern Mediterranean during the Ottoman Period. This is the first archaeological study of parasites in the Ottoman Empire. We analysed sediment from a latrine dating to the early 1800 s for the presence of helminth eggs and protozoan parasites which caused dysentery. The samples were examined using light microscopy and enzyme-linked immunosorbent assay (ELISA) kits. We found evidence for roundworm (Ascaris lumbricoides), whipworm (Trichuris trichiura), fish tapeworm (Dibothriocephalus sp.), Taenia tapeworm (Taenia sp.), lancet liver fluke (Dicrocoelium dendriticum), and the protozoa Giardia duodenalis and Entamoeba histolytica. The parasite taxa recovered demonstrate the breadth of species present in this coastal city. We consider the effect of Ottoman Period diet, culture, trade and sanitation upon risk of parasitism in this community living 200 years ago.
\end{abstract}

Key words: Dysentery, Mediterranean, Ottoman Empire, ELISA, helminth, paleoparasitology, protozoa

\section{INTRODUCTION}

The coastal city of Acre (or Akko), located in Israel, has a long history, with the earliest evidence for settlement coming from the Bronze Age (3000 BCE). It fell under Ottoman control following the Ottoman-Mamluk War of 1516-1517 [1]. At its height, the Ottoman Empire controlled large parts of south eastern Europe, the Near East, and the coast of North Africa. Acre was historically an important city in the Ottoman Empire until the early 19th century, when Beirut and Haifa were also used as major ports [2]. Combined with decades of conflict starting with the siege of Napoleon in 1799, conquest by Egypt in 1831, and re-conquering of Acre by the Ottomans in 1840 , this significantly affected the city's prosperity in the early 19th century [3].

The Ottoman Empire was quite tolerant with respect to the practise of religion within its boundaries [4]. Even so, the majority of the population living in Acre during this period practised Islam, with a minority practising Christianity and Judaism [5]. Due to Acre's importance as a port, a substantial

\footnotetext{
- Received 11 July 2019, revised 5 August 2019, accepted 20 August 2019.

*Corresponding author (pdm39@cam.ac.uk)

(C) 2019, Korean Society for Parasitology and Tropical Medicine

This is an Open Access article distributed under the terms of the Creative Commons Attribution Non-Commercial License (http://creativecommons.org/licenses/by-nc/4.0) which permits unrestricted non-commercial use, distribution, and reproduction in any medium, provided the original work is properly cited.
}

amount of trade also occurred there. This trade in animal products could potentially have introduced certain parasites that were not previously endemic to the region. These factors might have impacted the variety of intestinal parasites harboured by the community in Acre.

Intestinal parasites have been found at other archaeological sites in the Middle East in the Roman, Byzantine and medieval periods in regions such as Turkey [6,7], Egypt [8-10], Israel [1114], Bahrain [15], and Iran [16]. Species identified include roundworm, whipworm, Taenia sp. tapeworm, fish tapeworm, lancet liver fluke, Fasciola liver fluke, pinworm, and the protozoa Giardia duodenalis and Entamoeba histolytica. However, at most sites only a limited number of these species were present. It is unknown how widespread these species might have been, or which species were most common, within Ottoman culture. In consequence, this study of an Ottoman latrine at Acre has important implications for our understanding of the intestinal diseases of those who lived in the Ottoman Empire.

\section{MATERIALS AND METHODS}

The cesspit was excavated by the Israel Antiquities Authority and is located in the old city of Acre (Fig. 1). It was $1.75 \mathrm{~m}$ in diameter at the base, and its opening had been closed off in the past (Fig. 1). The walls of the cesspit were constructed using unhewn stones. It was dated to the early 1800 s based 

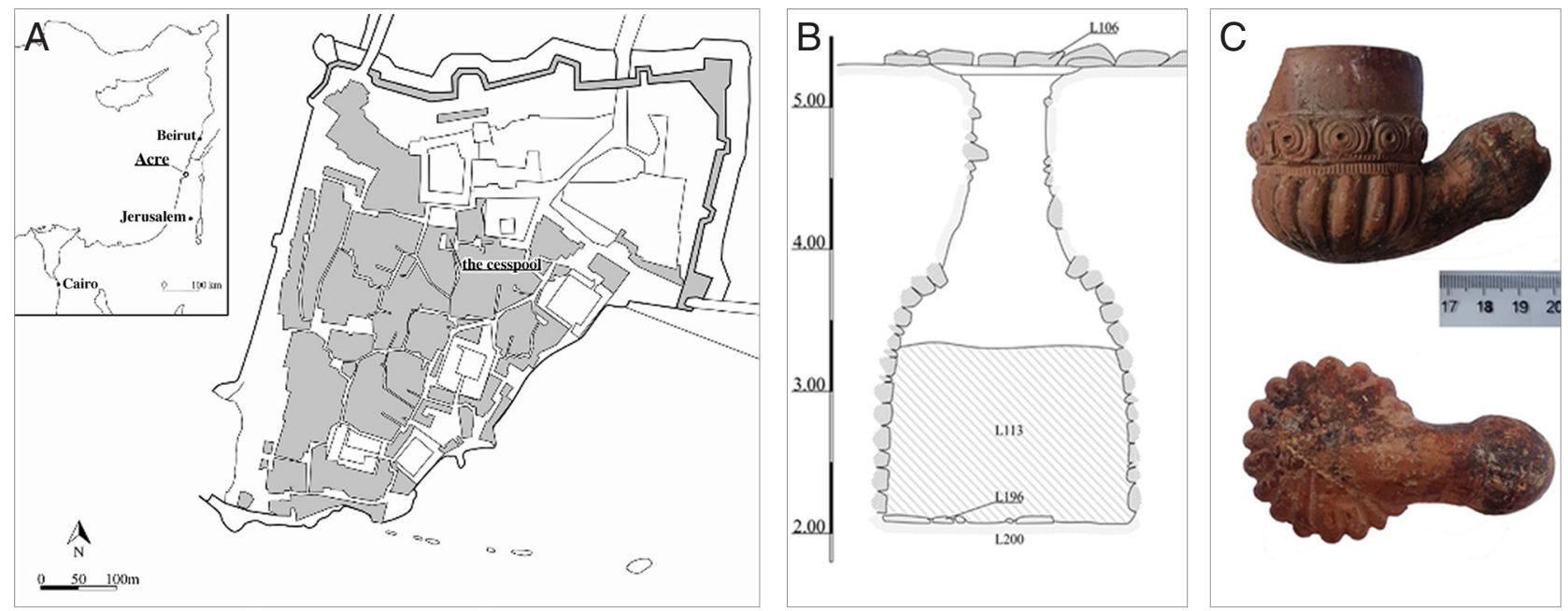

Fig. 1. Map showing the location of Acre in the eastern Mediterranean, and the location of the cesspool in the old city (A); cross sectional plan of the cesspit (B); Ottoman pipe dating to the early 1800s, which enables us to date the contents of the cesspool (C).

upon artefacts found within it, such as clay smoking pipes (Fig. 1, dated by Anastasia Shapiro of the Israel Antiquities Authority). Seven sediment samples were taken from different layers of the cesspit (samples 1-4, 7) and layers found underneath the cesspit floor (samples 5, 6).

The samples were analysed in the Ancient Parasites Laboratory at the University of Cambridge. From each sample a $0.2 \mathrm{~g}$ subsample was measured out for analysis. This quantity was used because it allows us to view about 20 slides for each sample, and the eggs per gram can be calculated by multiplying each egg count by a factor of 5 . This $0.2 \mathrm{~g}$ sediment sample was then disaggregated (made into a suspension) using an aqueous solution of $0.5 \%$ trisodium phosphate, as per the protocol followed in published studies from our laboratory $[6,17,18]$. The suspension was then poured through 3 microsieves in sequence, with mesh sizes of 300,160, and $20 \mu \mathrm{m}$, respectively. Intestinal helminth eggs most likely to be found in this region range from approximately $25 \mu \mathrm{m}$ to $150 \mu \mathrm{m}$ [19]. Therefore, all of the eggs present in each sample should be trapped on the $20 \mu \mathrm{m}$ micro-sieve. In order to evaluate the sediment for evidence of protozoa that can cause dysentery, the material in the catchment container below the $20 \mu \mathrm{m}$ micro-sieve (collected after passage through all 3 microsieves) was analysed using commercial enzyme-linked immunosorbent assay (ELISA) kits. This separation is possible due to the small size of Entamoeba histolytica, Cryptosporidium spp., and Giardia duodenalis cysts and preserved antigens, which are all below $20 \mu \mathrm{m}$ in diameter [19].
The ELISA kits used were the E. histolytica $\mathrm{II}^{\mathrm{TM}}$, Giardia $\mathrm{II}^{\mathrm{TM}}$, and Cryptosporidium II $^{\mathrm{TM}}$ kits produced by TECHLAB ${ }^{\circledR}$ (Blacksburg, Virginia, USA). Samples were analysed twice, on 2 separate days a month apart, and only considered positive if a positive result was present on both tests. A positive and negative control well were used on each ELISA plate, with the positive control being inactive antigen provided with the kits and the negative control being the diluent solution provided with the kits. The absorbance values for each well were measured using a BioTek Synergy HT Multi-Mode Microplate Reader. For the E. histolytica kit, the criterion for positive identification of a sample is an absorbance reading of at least 0.050 more than that of the negative control. For the Giardia and Cryptosporidium ELISA kits, a sample must yield a reading of at least 0.150 in order to be considered positive.

\section{RESULTS}

Intestinal helminth eggs were found in each subsample studied, but most samples only contained roundworm (Table 1). However, we will focus on the sediment from the base of the cesspool above the floor (sample 7) and adherent to the wall of the cesspool (sample 2) as they contained the best preserved parasites. Ascaris sp., Trichuris trichiura, Taenia sp. (beef/pork/asiatic tapeworm), Dibothriocephalus sp. (fish tapeworm) and Dicrocoelium dendriticum were found in the sediment analysed (Fig. 2). We have identified the Ascaris sp. as likely human roundworm (Ascaris lumbricoides, and not A. suum), notwithstanding 
Table 1. Parasite taxa found in each sample with mean dimensions, standard deviations and egg concentrations (eggs per gram)

\begin{tabular}{|c|c|c|c|c|}
\hline Parasite & Samples positive & Width $(\mu \mathrm{m})$ & Length ( $\mu \mathrm{m})$ & Eggs/g \\
\hline Ascaris lumbricoides & All & $\begin{array}{c}\text { Mean: } 45.8 \\
\text { SD: } 2.3\end{array}$ & $\begin{array}{c}\text { Mean: } 61.8 \\
\text { SD: } 4.0\end{array}$ & $30-355$ \\
\hline Trichuris trichiura & 2,7 & $\begin{array}{c}\text { Mean: } 25.7 \\
\text { SD: } 2.1\end{array}$ & $\begin{array}{c}\text { Mean: } 48.6 \\
\text { SD: } 2.9\end{array}$ & $5-25$ \\
\hline Taenia sp. & 7 & 32.1 & 35.4 & 5 \\
\hline Dibothriocephalus sp. & 7 & Mean: 39.7 & Mean: 65.0 & 10 \\
\hline Dicrocoelium dendriticum & 7 & 21.5 & 37.7 & 5 \\
\hline Entamoeba histolytica & 2 & - & - & - \\
\hline Giardia duodenalis & 7 & - & - & - \\
\hline
\end{tabular}
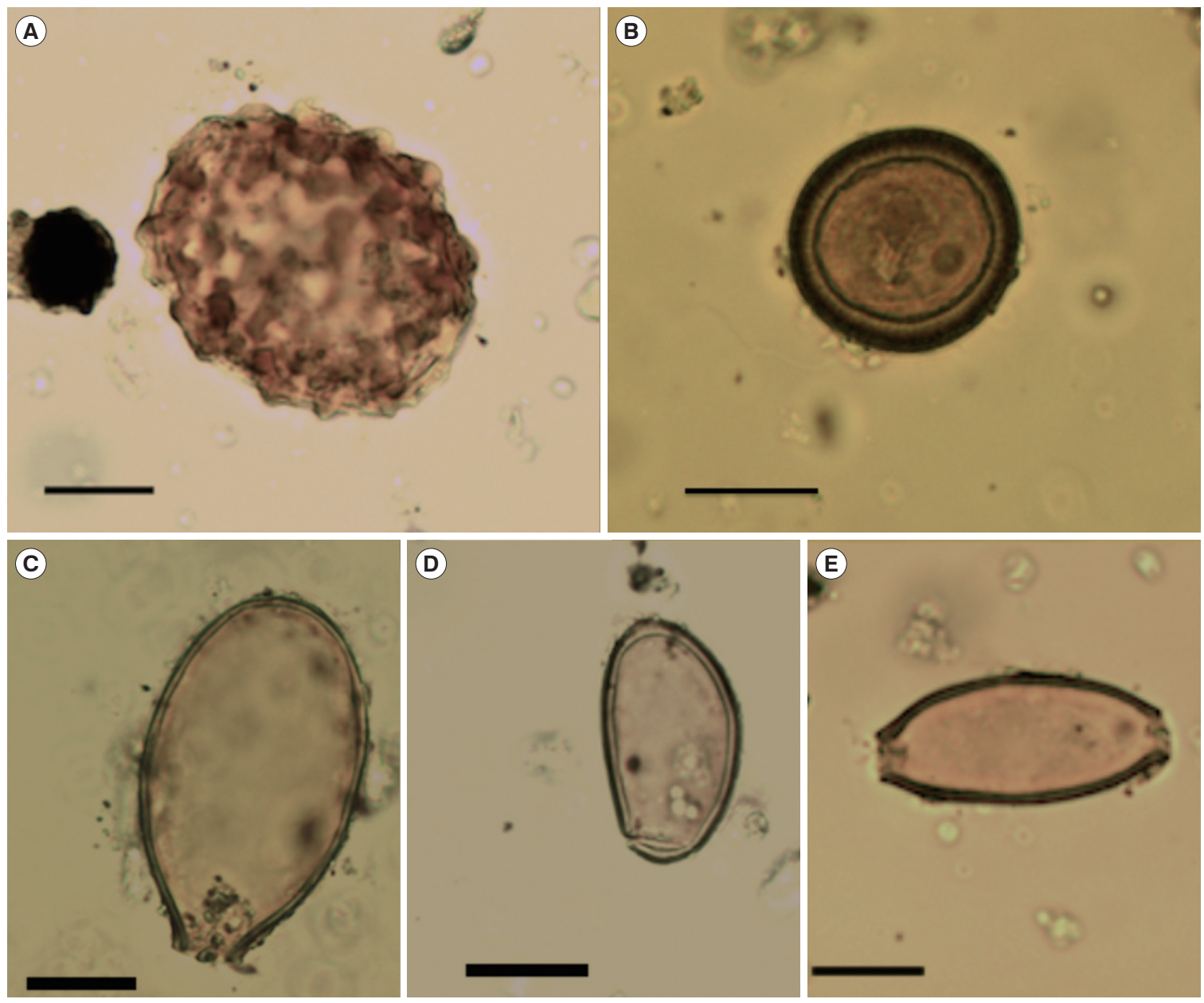

Fig. 2. Parasite eggs found in the Ottoman latrine from Acre, Israel. (A) Ascaris lumbricoides egg (dimensions $64 \times 51 \mu \mathrm{m})$; (B) Taenia sp.

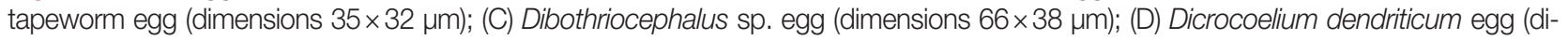
mensions $38 \times 21 \mu \mathrm{m})$; (E) Trichuris trichiura egg (dimensions $52 \times 24 \mu \mathrm{m})$. All black scale bars indicate $20 \mu \mathrm{m}$.

the similarity in morphology between human and pig roundworm, because the eggs were found in a human latrine [20].

Regarding protozoan parasites, Entamoeba histolytica and Giardia duodenalis were detected by ELISA. We carried out the ELISA tests twice, one month apart using fresh samples, to mi- nimise the risk of a false positive result. The Entamoeba histolytica ELISA test was positive in sample 2 for 7 out of the 8 wells on the first test, and for one of the 8 wells on the second test. The Giardia duodenalis ELISA test was positive in sample 7 for one of the 8 wells on the first test, and for 2 of the 8 wells on 
Table 2. Positive absorbance readings for the ELISA analysis of samples 2 and 7. Eight subsamples were tested on each occasion

\begin{tabular}{|c|c|c|c|c|}
\hline \multirow{2}{*}{ Parasite } & \multicolumn{2}{|c|}{ Sample 2} & \multicolumn{2}{|c|}{ Sample 7} \\
\hline & 1st test & 2nd test & 1st test & 2nd test \\
\hline \multirow[t]{7}{*}{ Entamoeba histolytica } & 0.681 & 0.088 & -ve & not required \\
\hline & 0.460 & & & \\
\hline & 0.653 & & & \\
\hline & 0.485 & & & \\
\hline & 0.152 & & & \\
\hline & 0.614 & & & \\
\hline & 0.551 & & & \\
\hline \multirow[t]{2}{*}{ Giardia duodenalis } & -ve & not required & 0.544 & 0.474 \\
\hline & & & & 0.323 \\
\hline Cryptosporidium parvum & -ve & not required & -ve & not required \\
\hline
\end{tabular}

the second test. In both ELISAs, all of the cesspit sediment samples tested negative for Cryptosporidium spp. (Table 2).

\section{DISCUSSION}

With the discovery of a range of intestinal helminth eggs and protozoa, we can begin to reconstruct a picture of intestinal health in this Ottoman city 200 years ago. The 2 helminth species found most commonly in the latrine sediment were roundworm and whipworm. This is what we would expect considering the previous studies in Israel dating from the Iron Age [21], Roman period [11,14,22], medieval period [13,23], and Mamluk period [18]. The finding of these 2 species in the cesspit sediment indicates that food and/or drinking water would have been contaminated with faeces.

We suspect the Taenia sp. is more likely to represent Taenia saginata (beef tapeworm) than T. solium or T. asiatica, due to the dietary restrictions against pork followed by the Muslims and Jews living in Acre at the time [24-26]. When beef was consumed in Ottoman communities, a common method of preparation was to cure it with salt, and this practise is common even today in Turkey. Cured/salted beef is known as pastirma in Turkish cuisine, and this food was co-opted by the Ottomans from the Byzantine Empire (where it was known as paston) [27]. If the meat was eaten cured but uncooked, this would have spread the parasite and so could explain the presence of Taenia sp. in the cesspit sediment.

Due to the morphological similarity and the extent of overlap in size dimensions between the eggs of Dibothriocephalus latus and Dibothriocephalus dendriticus $[28,29]$, we are unable to make a definitive diagnosis at the species level for the fish tapeworm eggs discovered. Although Dibothriocephalus latus is con- sidered the most common fish tapeworm species worldwide [30], Dibothriocephalus dendriticus has recently been recognised in a variety of recent cases in Europe, prompting conversations about its possible re-emergence as a parasite of humans-or rather an acknowledgement of its prospective impact on humans [31,32]. While Adenocephalus pacificus is a common species of fish tapeworm found in marine fish, it is not found in the Mediterranean region [33]. Therefore, our fish tapeworm eggs are most likely from a species which infects freshwater fish [34]. As fish tapeworm has been found in crusader period latrines in Acre [13], it is possible the parasite became endemic in the region and continued to infect people during the Ottoman period. An alternative scenario is that either travellers from other parts of the Ottoman Empire or Europe were infected elsewhere and then used this latrine when they moved to Acre, or that cured or smoked freshwater fish was brought to Acre by sea and sold, so infecting the local population. Since the Ottomans controlled the Balkans, and since that region is known to have a significant burden of fish tapeworm infection [35], this may have been the source of fish tapeworm transmission in the Ottoman Empire. Indeed, the ruler of Acre from 1776 to 1804 , Ahmad al Jazzâr, was born in Bosnia.

Although the prevalence of Dicrocoelium dendriticum in humans appears to be higher in the Near East than other regions across the globe [36], it is unlikely that the egg found is indicative of genuine human infection. Due to the low number of eggs found, it is more likely that someone using the cesspit had eaten the raw or undercooked liver of an infected farm animal, with the eggs passing harmlessly though their intestines. Indeed, a popular dish in Ottoman cuisine was lamb or veal liver, known as Arnavut cigeri or "Albanian liver", adopted when the Ottomans controlled much of the Balkans [37]. This 
scenario would be an example of pseudoparasitism, in which the human was not a true definitive host - the person would not have been infected with adult $D$. dendriticum worms or have experienced any clinical symptoms.

The findings of Entamoeba histolytica and Giardia duodenalis in the latrine samples give further evidence for the level of sanitation and hygiene in this period, as they are spread by the contamination of food and drink by faeces [19]. With microscopic analysis alone E. histolytica is indistinguishable from $E$. dispar (a non-pathogenic organism), due to the identical nature of these species' morphology [38]. In contrast, ELISA is able to distinguish these 2 species [39]. In addition, ELISA is more sensitive than light microscopy for the detection of these dysentery-causing protozoa due to their poor preservation in archaeological samples [12,40]. Entamoeba histolytica and Giardia duodenalis have previously been identified in the region in medieval latrines at Acre and a Mamluk period latrine in Jerusalem $[12,18]$. Drinking water in the Ottoman Empire came from wells, springs and rainwater collected in cisterns, and was transported by aqueducts and cylindrical terracotta pipes. It was common for wastewater to drain into the sewage networks, which led to latrines (located throughout Ottoman cities) or to nearby rivers [41]. The often sophisticated water networks, with separate channels for wastewater and clean water, were made possible by waqfs, or religious endowments [42]. However, with the discovery of these intestinal protozoa in the latrine sediment, it does appear that the Ottoman sewage infrastructure was not sufficient to prevent the population from contracting dysentery.

To conclude, the diversity of parasite species found in this latrine is appreciably higher than most previous studies of past populations of the Middle East region. This may be a consequence of the town's role in trade, as a coastal city at the border of a large empire. Because of the noticeable lack of past analyses of Ottoman samples, this study helps us to understand the health consequences of the culture, sanitation, diet, and migration patterns within the Ottoman Empire. With our findings of A. lumbricoides, T. trichiura, G. duodenalis and E. histolytica, we can infer that hygiene and sanitation infrastructure did not prevent the spread of intestinal diseases in Ottoman Acre. Our findings of Dibothriocephalus sp., Taenia sp., and Dicrocoelium dendriticum, show that foods consumed by the Acre residents may not have always been adequately cooked. In addition, the discovery of Dibothriocephalus sp. might indicate migration from, or trade with, other Ottoman regions such as the Balkans.

\section{ACKNOWLEDGMENT}

The ELISA test kits were donated by Techlab ${ }^{\odot}$, Blacksburg, USA.

\section{CONFLICT OF INTEREST}

The authors declare no conflict of interest related to this study.

\section{REFERENCES}

1. Shaw SJ. History of the Ottoman Empire and Modern Turkey, Vol. 1: Empire of the Gazis: The Rise and Decline of the Ottoman Empire 1280-1808. Cambridge, UK. Cambridge University Press. 1976.

2. Ben-Bassat Y, Ben-Artzi Y. Cartographical evidence of efforts to develop Acre during the last decades of Ottoman rule: did the Ottomans neglect the city? Medit Hist Rev 2016; 31: 65-87.

3. Sharon M. Corpus Inscriptionum Arabicarum Palaestinae. Leiden, Netherlands. Brill. 1997.

4. Howard DA. A History of the Ottoman Empire. Cambridge, UK. Cambridge University Press. 2017.

5. Panzac D. International and domestic maritime trade in the Ottoman Empire during the 18th century. Int J Middle East Stud 1992; 24: 189-206.

6. Ledger ML, Stock F, Schwaiger H, Knipping M, Brückner H, Ladstätter S, Mitchell PD. Intestinal parasites from public and private latrines and the harbour canal in Roman Period Ephesus, Turkey (1st c. BCE to 6th c. CE). J Archaeol Sci Rep 2018; 21: 289-297.

7. Williams FS, Arnold-Foster T, Yeh HY, Ledger ML, Baeten J, Poblome J, Mitchell PD. Intestinal parasites from the 2nd-5th century AD latrine in the Roman Baths at Sagalassos (Turkey). Int J Paleopathol 2017; 19: 37-42.

8. Bruschi F, Masetti M, Locci MT, Ciranni R, Fornaciari G. Short report: cysticercosis in an Egyptian mummy of the late Ptolemaic period. Am J Trop Med Hyg 2006; 74: 598-599.

9. Harter S, Le Bailly M, Janot F, Bouchet F. First paleoparasitological study of an embalming rejects jar found in Saqqara, Egypt. Mem Inst Oswaldo Cruz 2003; 98: 119-121.

10. Le Bailly M, Mouze S, da Rocha GC, Heim JL, Lichtenberg R, Dunand F, Bouchet F. Identification of Taenia sp. in a mummy from a Christian Necropolis in El-Deir, Oasis of Kharga, ancient Egypt. J Parasitol 2010; 96: 213-215.

11. Harter S, Bouchet F, Mumcuoglu KY, Zias JE. Toilet practices among members of the Dead Sea Scrolls sect at Qumran (100 BCE-68 CE). Rev Qumran 2004; 21: 579-584.

12. Mitchell PD, Stern E, Tepper Y. Dysentery in the crusader kingdom of Jerusalem: an ELISA analysis of two medieval latrines in the City of Acre (Israel). J Archaeol Sci 2008; 35: 1849-1853. 
13. Mitchell PD, Anastasiou E, Syon D. Human intestinal parasites in crusader Acre: evidence for migration with disease in the medieval period. Int J Paleopathol 2011; 1: 132-137.

14. Witenberg G. Human parasites in archaeological findings. Bull Israel Explor Soc 1961; 25: 86.

15. Søe MJ, Nejsum P, Seersholm FV, Fredensborg BL, Habraken R, Haase K, Hald MM, Simonsen R, Højlund F, Blanke L, Merkyte I, Willerslev E, Kapel CMO. Ancient DNA from latrines in Northern Europe and the Middle East (500 BC-1700 AD) reveals past parasites and diet. PLoS One 2018; 13: e0195481.

16. Nezamabadi M, Aali A, Stöllner T, Mashkour M, Le Bailly M. Paleoparasitological analysis of samples from the Chehrabad salt mine (Northwestern Iran). Int J Paleopathol 2013; 3: 229-233.

17. Anastasiou E, Mitchell PD. Human intestinal parasites from a latrine in the 12th century Frankish castle of Saranda Kolones in Cyprus. Int J Paleopathol 2013; 3: 218-223.

18. Yeh HY, Prag K, Clamer C, Humbert JB, Mitchell PD. Human intestinal parasites from a Mamluk Period cesspool in the Christian quarter of Jerusalem: potential indicators of long distance travel in the 15th century AD. Int J Paleopathol 2015; 9: 69-75.

19. Garcia LS. Diagnostic Medical Parasitology. 5th ed. Washington DC, USA. ASM Press. 2007.

20. Ansel M, Thibaut M. Value of the specific distinction between Ascaris lumbricoïdes Linné 1758 and Ascaris suum Goeze 1782. Int J Parasitol 1973; 3: 317-319.

21. Cahill JM, Reinhard K, Tarler D, Warnock P. It had to happen. Scientists examine remains of ancient bathroom. Bibl Arch Rev 1991; 17: 64-69.

22. Zias JE, Tabor JD, Harter-Lailheugue S. Toilets at Qumran, the Essenes, and the scrolls: new anthropological data and old theories. Rev Qumran 2006; 22: 631-640.

23. Mitchell PD, Tepper Y. Intestinal parasitic worm eggs from a crusader period cesspool in the city of Acre (Israel). Levant 2007; 39: 91-95.

24. Deuteronomy 14:8, Holy Bible: King James Version. Collins. 2011.

25. Leviticus 11:7, Holy Bible: King James Version. Collins. 2011.

26. Abdel Haleem MAS. The Qur'an: A New Translation by M.A.S. Abdel Haleem. Oxford, UK. Oxford University Press. 2008, 2: 173.

27. Smith AF, Kraig B. The Oxford Encyclopedia of Food and Drink in America. 2nd ed. Oxford, UK. Oxford University Press. 2013.

28. Choi S, Cho J, Jung BK, Kim DG, Jeon SJ, Jeon HK, Eom KS, Chai JY. Diphyllobothrium nihonkaiense: wide egg size variation in 32 molecularly confirmed adult specimens from Korea. Parasitol Res 2015; 114: 2129-2134.

29. Leštinová K, Soldánová M, Scholz T, Kuchta R. Eggs as a suitable tool for species diagnosis of causative agents of human diphyllobothriosis (Cestoda). PLoS Negl Trop Dis 2016; 10: e0004721.
30. Adams AM, Rausch RL. Diphyllobothriasis. In Connor DH, Chandler FW, Schwartz DA, Manz HJ, Lack EE eds, Pathology of Infectious Diseases. Stamford, USA. McGraw-Hill Professional. 1997, pp. 1377-1390.

31. de Marval F, Gottstein B, Weber M, Wicht B. Imported diphyllobothriasis in Switzerland: molecular methods to define a clinical case of Diphyllobothrium infection as Diphyllobothrium dendriticum, August 2010. Euro Surveill 2013; 18: 20355.

32. Wicht B, de Marval F, Gottstein B, Peduzzi R. Imported diphyllobothriasis in Switzerland: molecular evidence of Diphyllobothrium dendriticum (Nitsch, 1824). Parasitol Res 2008; 102: 201-204.

33. Hernández-Orts JS, Scholz T, Brabec J, Kuzmina T, Kuchta R. High morphological plasticity and global geographical distribution of the Pacific broad tapeworm Adenocephalus pacificus (syn. Diphyllobothrium pacificum): molecular and morphological survey. Acta Trop 2015; 149: 168-178.

34. Bennett JE, Dolin R, Blaser MJ. Mandell, Douglas, and Bennett's Principles and Practice of Infectious Diseases. 8th ed. Philadelphia, USA. Elsevier. 2015.

35. Auer H, Aspöck H. Helminths and helminthoses in Central Europe: diseases caused by cestodes (tapeworms). Wien Med Wochenschr 2014; 164: 414-423.

36. Mowlavi G, Mokhtarian K, Makki MS, Mobedi I, Masoumian M, Naseri R, Hoseini G, Nekouei P, Mas-Coma S. Dicrocoelium dendriticum found in a Bronze Age cemetery in western Iran in the pre-Persepolis period: the oldest Asian palaeofinding in the present human infection hottest spot region. Parasitol Int 2015; 64: 251-255.

37. Kia M. Daily Life in the Ottoman Empire. Santa Barbara, USA. ABC-CLIO. 2011.

38. Diamond LS, Clark CG. A redescription of Entamoeba histolytica Schaudinn, 1903 (emended Walker, 1911) separating it from Entamoeba dispar Brumpt, 1925. J Eukaryot Microbiol 1993; 40: 340-344.

39. Sharp SE, Suarez CA, Duran Y, Poppiti RJ. Evaluation of the Triage Micro Parasite Panel for detection of Giardia lamblia, Entamoeba histolytica/Entamoeba dispar, and Cryptosporidium parrum in patient stool specimens. J Clin Microbiol 2001; 39: 332-334.

40. Gonçalves ML, Araújo A, Duarte R, da Silva JP, Reinhard K, Bouchet F, Ferreira LF. Detection of Giardia duodenalis antigen in coprolites using a commercially available enzyme-linked immunosorbent assay. Trans R Soc Trop Med Hyg 2002; 96: 640-643.

41. Disli G, Özcan Z. Waste and clean water systems in Anatolian Seljuk and Ottoman period hospitals. International Journal of Academic Research Part A 2014; 6: 169-177.

42. Saduman S, Aysun EE. The socio-economic role of waqf system in the Muslim-Ottoman cities' formation and evolution. Trakia J Sci 2009; 7: 272-275. 